\title{
1. DRILLING ON THE GOBAN SPUR: OBJECTIVES, REGIONAL GEOLOGICAL SETTING, AND OPERATIONAL SUMMARY ${ }^{1}$
}

\author{
P. C. de Graciansky, École Nationale Supérieure des Mines \\ C. Wylie Poag, U.S. Geological Survey, Woods Hole \\ and \\ Glen Foss, Deep Sea Drilling Project ${ }^{2}$
}

\section{DRILLING OBJECTIVES}

Deep Sea Drilling Project Leg 80 investigated the structural evolution and depositional history of the Goban Spur and the adjacent Porcupine Abyssal Plain (Fig. 1). This is the second DSDP leg devoted to documenting the development of the continental margin of northwest Europe. During the first leg (Leg 48), Sites 400 to 402 were drilled on the Armorican margin, $250 \mathrm{~km}$ southeast of the Goban Spur (Montadert, Roberts, et al., 1979). The Leg 48 investigation was incomplete because the drill string was lost at the deepest site (400), but the results were nevertheless significant for understanding the evolution of passive margins.

Structural relationships and fossil assemblages indicate that the rifting of the Armorican margin created submarine relief of as much as $2000 \mathrm{~m}$ (Montadert, Roberts, et al., 1979). Seafloor spreading began no later than the early Aptian and was accompanied by rapid crustal subsidence in the form of regional downwarping and tilting. Subsidence was greatest near the ocean/continent juncture and diminished farther toward the continent, where the crust is thicker. Subsidence has been minimal since the Eocene, and deposition since the Eocene has been strongly influenced by oceanic circulation patterns and water chemistry. As the Cenozoic deposition proceeded, the continental slope grew outward, growth clearly recorded in the lithofacies and unconformities penetrated by the Leg 48 drill holes.

We placed Sites 548 to 551 along a transect across the continent/ocean boundary on the sediment-starved Goban Spur (Figs. 1 and 2) to attempt the following: (1) to establish the geologic ages, lithofacies, depositional environments, and subsidence rates of the pre-, syn-, and post-rift phases of development of the continental margin; (2) to determine the duration of rifting and the age and nature of the post-rift unconformity; (3) to document the age and nature of significant post-rift chronostratigraphic boundaries and prominent seismic unconformities and assess the relationships between these fea-

\footnotetext{
${ }^{1}$ Graciansky, P. C. de, Poag, C. W., et al., Init. Repts. DSDP, 80: Washington (U.S. Govt, Printing Office).

2 Addresses: (Graciansky) École Nationale Supérieure des Mines, Géologie Générale et Minière, 60, Boulevard Saint-Michel, 75272 Paris Cedex 06; (Poag) U.S. Geological Survey, Woods Hole, Massachusetts 02543; (Foss) Deep Sea Drilling Project, Scripps Institution of Oceanography, La Jolla, California 92093.
}

tures and the processes of basin subsidence, global sea level changes, and tectonism; (4) to analyze the effects of changing paleoceanographic conditions (paleodepths, paleoclimates, rates of subsidence, and rates of deposition) upon the accumulation, composition, and erosion of continental margin sediments; (5) to determine heat flow rates and other aspects of the thermal regime of this margin and acquire additional information about the crustal thinning near the continent/ocean boundary; and (6) to compare and correlate the geologic and geophysical record of this continental margin with the known record for other margins, for the deep sea, and for the adjacent European landmass.

\section{REGIONAL GEOLOGICAL SETTING}

\section{Geologic Provinces}

The Biscay region has been involved in several phases of rifting, drifting, and the convergence of Europe, Iberia, Africa, and North America, and its geological structure is complex (Naylor and Shannon, 1983). Bathymetry and structural relationships suggest that four geologic provinces can be recognized in the northern Biscay region (Fig. 1). They are, from southeast to northwest, as follows:

1. The narrow and steep Armorican margin (Aquitaine to the Western Approaches Basin), which rests on a thin continental crust and is bordered on the southwest by the deep Mesozoic-Cenozoic Armorican Marginal Basin.

2. The broad Western Approaches margin, which contains several prominent topographic features (such as the Meriadzek Terrace, the Trevelyan Escarpment, and Shamrock Canyon; Fig. 2A) and intersects the Mesozoic-Cenozoic Western Approaches Basin. Its southeastern boundary with the Armorican margin, near Black Mud Canyon, is very sharp.

3 . The relatively shallow (maximum 2000-m water depth) Goban Spur, which is generally broad and smooth but deepens abruptly along the Pendragon Escarpment (Fig. 2A). It is formed over a basement high that is the prolongation of Cornwall (the Cornubian Platform). Its connection with the Western Approaches margin is marked by several protruding topographic features, such as Granite Cliff and Austell Spur. These in turn are separated by large canyons that trend northwest-southeast. 


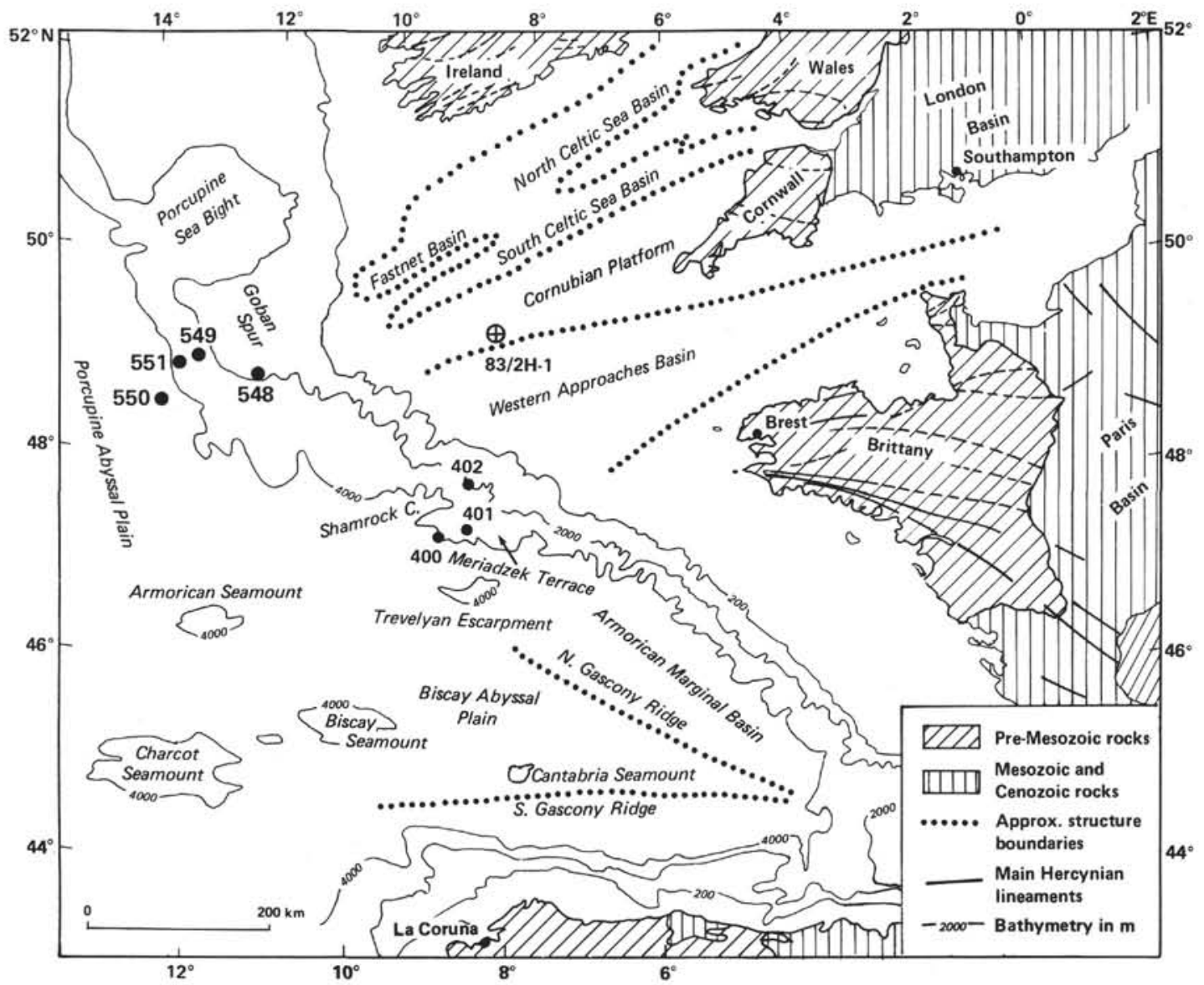

Figure 1. Location of sites drilled during DSDP Legs 48 (Sites 400-402) and 80 (Sites 548-551). Depths are in m below sea level; regional ages refer to age of surficial rocks. Base map after Montadert, Roberts, de Charpal, et al. (1979).

4. The Porcupine Sea Bight, a depression that corresponds to a deep Mesozoic-Cenozoic sedimentary basin.

\section{Seismic Basement}

In the northern Biscay-Goban Spur region, seismic basement is distinguished from the overlying sediments by either its diffractive character (if the crust is oceanic) or the presence of dipping reflections (if the crust is continental). The continental basement rocks are divided by listric normal faults (Bally et al., 1981) into large tilted blocks of different heights, the upper surfaces of which slope landward, forming half-grabens (Montadert, Roberts, et al., 1979; Roberts et al., 1981; Figs. 3 and 4). Oceanic basement can be also identified independently by its pattern of marked magnetic anomalies (Roberts and Jones, 1975) and its seismic refraction characteristics. Before Leg 80 neither oceanic nor continental basement rocks had been drilled seaward of the continental shelf, although several dredges had recovered granitoids, metasedimentary rocks, and shallow-water carbonates and sandstones of late Paleozoic age from the Hercynian continental basement in the vicinity of the Goban Spur (Pautot et al., 1976; Auffret et al., 1979). The seawardmost released well on the continental shelf in the Western Approaches Basin (Zephyr 83/2H-1; Fig. 1) penetrated a $140-\mathrm{m}$ basement succession of Hercynian slates, mudstones, and sandstones, which on the basis of comparison with onshore sections are believed to be Devonian to Carboniferous in age (Evans et al., 1981). Above this basement there is a 51-m series of undated red brown mudstones, siltstones, and sandstones that contain traces of anhydrite. These beds appear to represent syn-rift deposition and have been tentatively assigned an age of Permo-Triassic. However, other shelf and slope studies have suggested that rifting began during either the Early Cretaceous or the Middle Jurassic (Kamerling, 1979; Robinson et al., 1981; Roberts et al., 1981).

\section{Syn-Rift Deposits}

Thick sediments accumulated in the half-grabens during rifting (seismic Formation 4 of Montadert, Roberts, de Charpal, et al., 1979; Roberts, et al., 1981). They are generally characterized by seismic reflections that converge toward the crests of the basement blocks. On the tops of the blocks, many of which are truncated, these strata are generally thin or absent, although the distribution of the syn-rift sediments is complex as a result of complex faulting (Fig. 4). In terms of total thickness, 


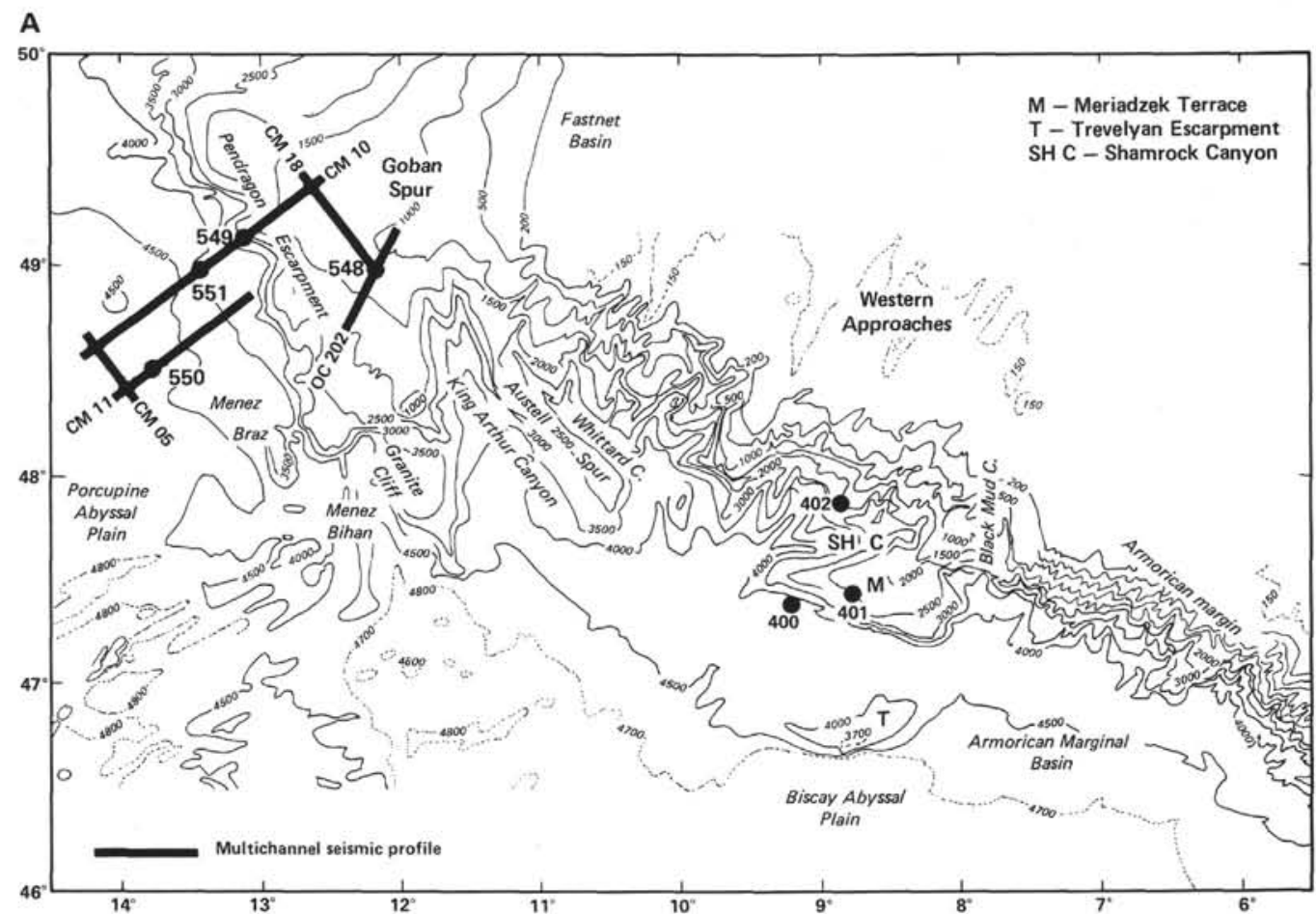

B SW

NE

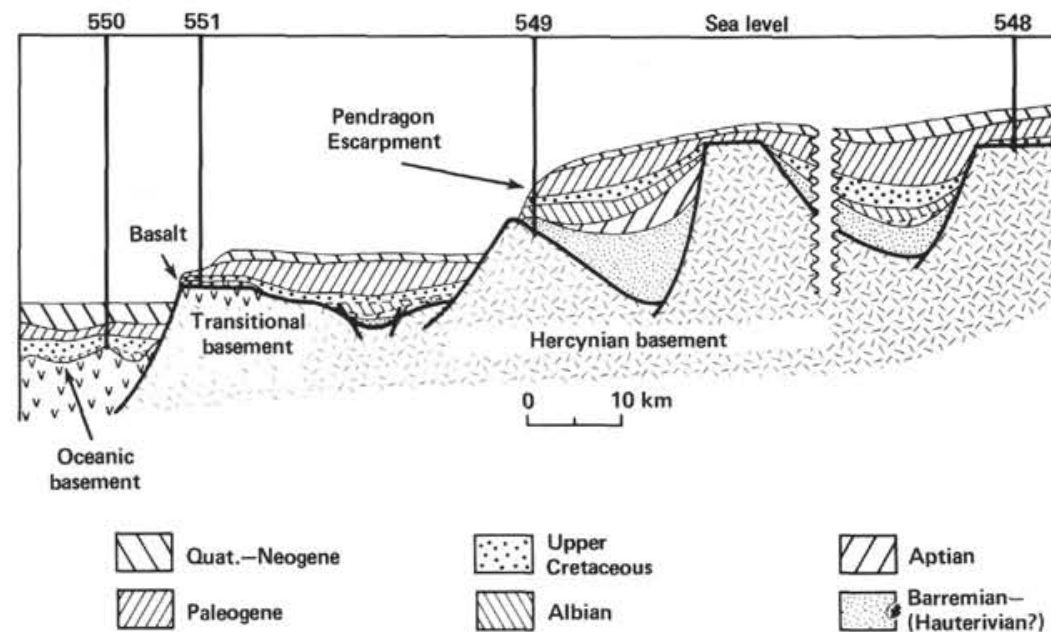

Figure 2. A. Bathymetry near sites drilled during Legs 48 and 80 . Depths are in $\mathrm{m}$ below sea level. Base map from Montadert, Roberts, de Charpal, et al. (1979). B. Schematic geologic section across Goban Spur showing sites drilled during Leg 80 . Section is approximately coincident with multichannel seismic line CM 10. Sites 548 and 550 are projected northwestward to the line of section, whereas Sites 549 and 551 are on the line.

the sediments on the Goban Spur are much thinner as a rule than those on the Armorican margin (Montadert, Roberts, et al., 1979).

A high amplitude, unconformable seismic reflector commonly marks the truncated upper surfaces of the tilted basement blocks and forms the upper boundary of some of the syn-rift sedimentary wedges, separating the syn-rift from the post-rift sediments. This post-rift unconformity apparently was penetrated by Hole 401 , which was drilled over a basement high on Leg 48 (Montadert, Roberts, et al., 1979; Fig. 3). The deposits beneath the unconformity are shallow-water carbonates of
Kimmeridgian to Berriasian age. Because Site 401 was on a basement high, the limestones may be just a local bank top accumulation. Nevertheless, dredging has revealed the presence of similar Upper Jurassic limestones on the Meriadzek Terrace and elsewhere in the vicinity (Auffret et al., 1979), suggesting that these units could have been part of a broad syn-rift carbonate platform. In addition, several small isolated reefs or carbonate banks have been tentatively identified within the syn-rift wedges on the Goban Spur (Masson and Roberts, 1981). At Site 401, the oldest sediments recovered above the post-rift unconformity are late Aptian in age, although 


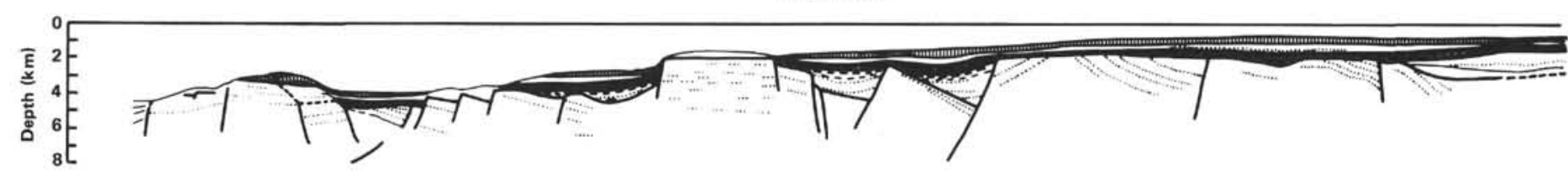

$50 \mathrm{~km}$

Western Approaches Margin
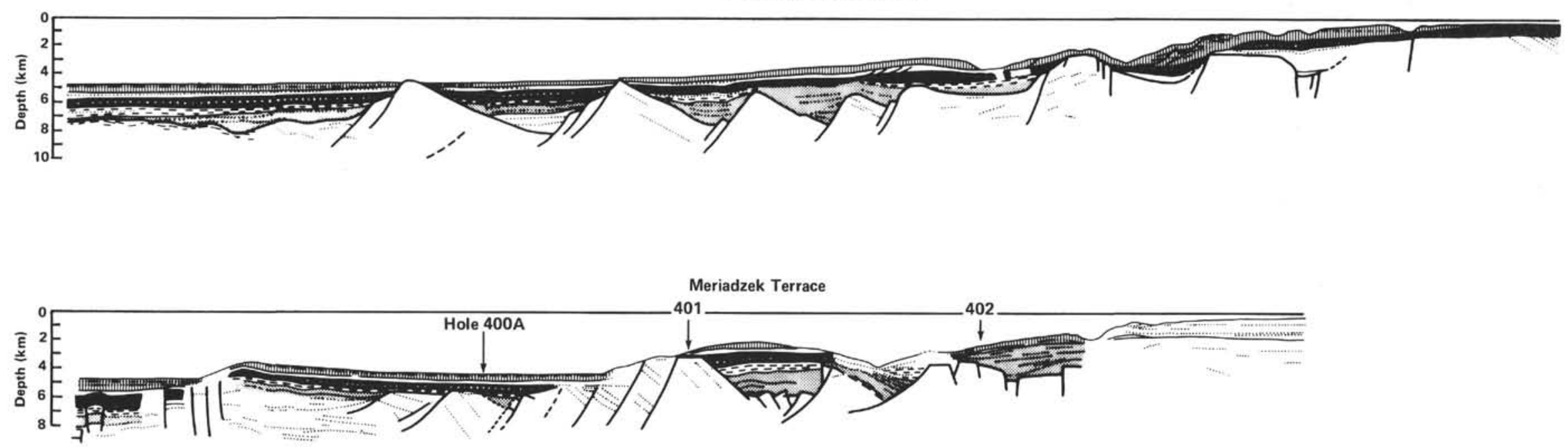

Quaternary-Oligocene

middle Eocene-Upper Cretaceous

Figure 3. Schematic structural sections across the continental margin of northwest Europe (from Montadert, Roberts, de Charpal, et al., 1979). Vertical exaggeration $=2: 5$.

\section{포 Albian-Aptian \\ $\square$ Syn-rift (Lower Cretaceous-Upper Jurassic) \\ [1] Faulted basement \\ Seismic reflectors}




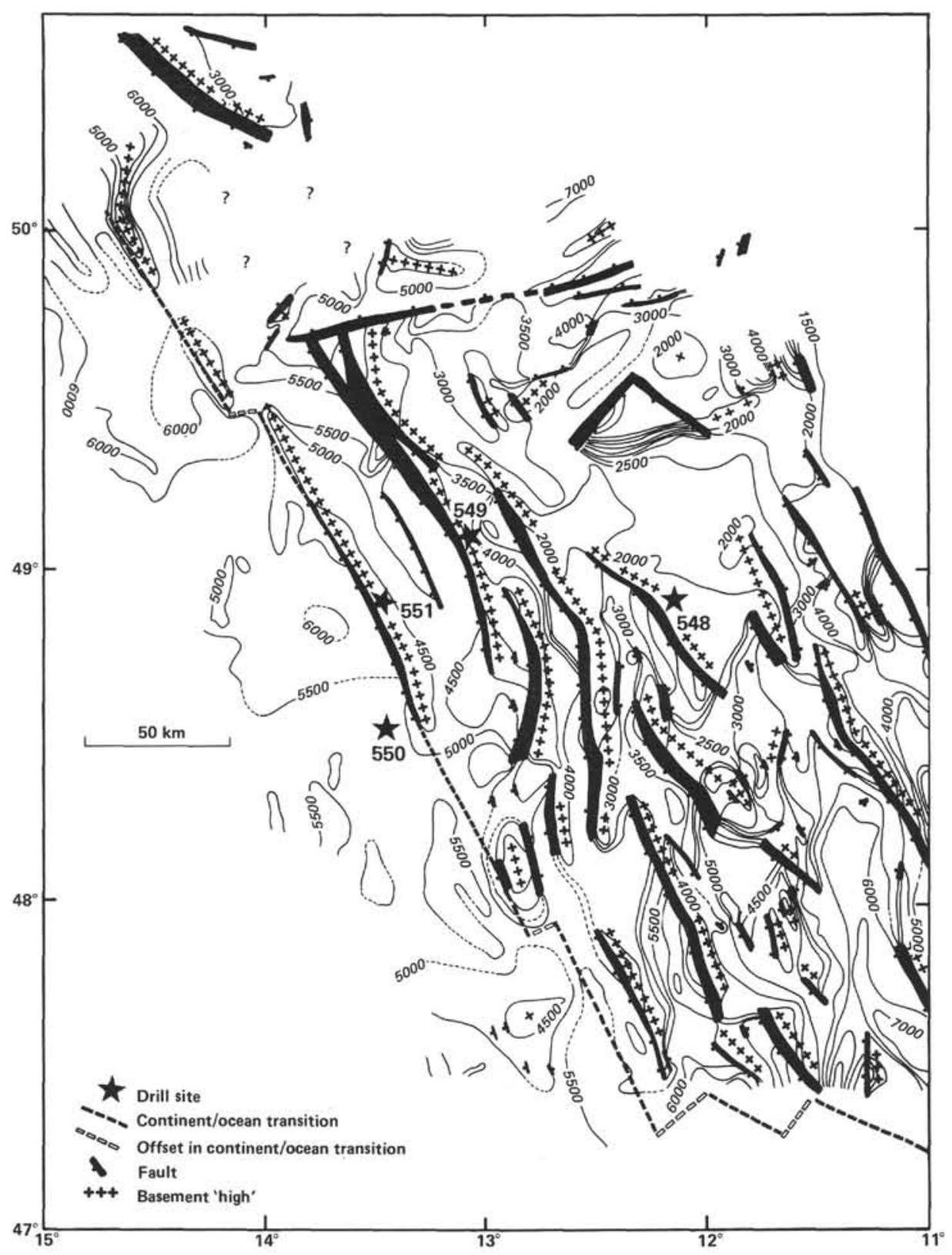

Figure 4. Fault pattern across Goban Spur and vicinity (after Masson et al., this volume). Contours show depth (in m) to acoustic basement.

the unconformity itself was not penetrated. At Site 402, however, where the post-rift unconformity was penetrated, lower Aptian limestones lie directly above it (Montadert, Roberts, et al., 1979). Therefore, all pre-Aptian Mesozoic rocks have been considered as possible synrift deposits. Dredging has produced a variety of such rocks. Shallow-water micritic limestones or marly chalks (Barremian) and deep-water ammonite-bearing marls (Hauterivian-Valanginian) have been recovered from the vicinity of Shamrock Canyon (Auffret et al., 1979; Pastouret et al., 1981). Valanginian to Barremian shallowwater limestones and chalks have been dredged on the Meriadzek Escarpment (Pastouret et al., 1981).

\section{Post-Rift Deposits}

The results of the Leg 48 drilling on the Armorican margin (Sites 400-402) showed that the oldest post-rift sediments in the Meriadzek area are of early Aptian age (lower part of seismic Formation 3 of Montadert, Roberts, de Charpal, et al., 1979). The correlation of seismic and stratigraphic data from the Western Approaches Basin (Fig. 1) demonstrates that beneath the continental shelf, the oldest post-rift sediments are middle Albian (Evans et al., 1981; Roberts et al., 1981).

In terms of Aptian topography, there may have been one or several isolated shallow banks seaward of the con- 
tinental shelf in the area of the Meriadzek Plateau (Fig. 1), but otherwise this was a deep-water region. Because the post-rift sediments are not displaced by the listric faults (Montadert, Roberts, de Charpal, et al., 1979), and because Site 401 is believed to have been near sea level during the Aptian, the depth at which Aptian sediments were deposited at Site 400 was estimated from the present difference in the depth of the basement blocks at Sites 401 and 400 , which is approximately $2000 \mathrm{~m}$. It has been speculated that most of the Goban Spur area must have been much shallower, because the basement blocks there are truncated and truncation is believed to indicate proximity to sea level (Montadert, Roberts, de Charpal, et al., 1979; Roberts et al., 1981). At the end of rifting only a narrow deep trough is thought to have existed there. This tectonic difference between the Meriadzek and Goban Spur areas may be a consequence of the difference in the composition of the pre-rift basement rocks. On the Goban Spur, rifting affected a Hercynian granite and metasedimentary basement, but in the Meriadzek area, rifting affected a Hercynian basement that is probably of different composition (Montadert, Roberts, de Charpal, et al., 1979). This difference would suggest that the tectonics of a rift system may be greatly influenced by the composition and structure of pre-rift rocks.

Post-rift deposition has been strongly influenced by regional subsidence, changes in oceanic circulation, and changes in water chemistry, as revealed by, respectively, prominent unconformities, paleotemperature changes, and variations in the relative abundance of biogenic silica and carbonate. These changes appear to have occurred rapidly and are thought to be related to global paleoclimatic and paleoceanographic events.

\section{Major Unconformities}

A number of marked unconformities are visible on multichannel seismic reflection profiles that cross the northern margin of the Bay of Biscay. The chronostratigraphic position of these unconformities and the duration of the hiatuses they represent have been estimated from long-distance seismic correlations between the sites drilled on this margin during Leg 48 (Montadert, Roberts, et al., 1979) and wells on the shelf (Western Approaches Basin). The most widespread and easily recognized unconformity is the Aptian/pre-Aptian unconformity, which separates syn-rift from post-rift sediments (forms the boundary between seismic Formations 4 and 3). The basement blocks were truncated during this interval.

Another seismic (and biostratigraphic) unconformity separates Upper Cretaceous chalks from Aptian-Albian black shales (forms the boundary between seismic Formations 3 and 2). This unconformity is documented for Site 400 (Montadert, Roberts, de Charpal, et al., 1979). An unconformity of similar age is known in many parts of the North Atlantic Basin; it appears to have been produced by global paleoceanographic changes, including changes in sea level, that took place during the Cenomanian (Vail et al., 1977).

Another seismic unconformity occurs on top of Upper Cretaceous to upper Eocene deposits. This uncon- formity can be identified by the marked truncation of the underlying reflections (and forms the boundary between seismic Formations 2 and 1; Montadert, Roberts, de Charpal, et al., 1979). This erosive event could not be dated with precision before Leg 80; it was thought to postdate a middle Eocene oceanographic change that is marked at many North Atlantic sites by a sharp increase in silica production (Tucholke and Vogt, 1979; Roberts and Montadert, 1979). The Eocene paleoceanographic event may have resulted from a change in plate motion and is linked to the widespread onset of strong bottom water currents that eroded some areas but built sediment waves, drifts, and dunes in others (Roberts, 1975; Montadert, Roberts, de Charpal, et al., 1979; Tucholke and Vogt, 1979).

Several other seismic unconformities appear in the post-Eocene sediments on the Goban Spur. These unconformities, which are particularly visible in seismic profiles that cross the slope, may be related to global changes in sea level (Vail et al., 1977; Roberts et al., 1981).

\section{Geology of the Goban Spur}

The Goban Spur is structurally similar to the Armorican margin in that the basement is broken up by a series of related listric normal faults, the throw of which is consistently southwest (down to the basin; Fig. 4). In both areas dipping reflections characterize the syn-rift graben fill. The major difference is that the Goban Spur has remained structurally higher than the Armorican margin, and thus the post-rift sedimentary cover is considerably thinner (Fig. 3; Roberts et al., 1981). These conditions are ideal for sampling syn-rift deposits and basement rocks by open-hole drilling; re-entry is usually unnecessary.

The continent/ocean boundary adjacent to the Goban Spur is marked at some locations by a low west-facing escarpment and a change in seismic character from strongly diffracting oceanic basement to the dipping reflections characteristic of the tilted continental fault blocks. It is also marked in places by a large fault (Fig. 4) and a prominent magnetic anomaly (Scrutton, 1979; Dingle and Scrutton, 1979). In other places, however, the boundary is more difficult to detect.

The crests of the fault blocks, and the upper strata of some of the syn-rift sequences as well, are typically truncated horizontally by the well-developed post-rift erosion surface, and this surface can be followed downslope to the continent/ocean boundary. An analysis that incorporates the seismic stratigraphy of the Goban Spur and vicinity, the magnetic signatures of the adjacent seafloor, and the drilling results of Leg 48 (prior to Leg $80)$ suggested that the transition from rifting to spreading took place at the western edge of Goban Spur some time in the Late Cretaceous (between the Albian and Campanian; Roberts et al., 1981).

\section{OPERATIONAL SUMMARY}

Leg 80 commenced on 30 May 1981 at Brest, France, and it terminated on 22 July 1981 at Southampton, England (Fig. 1). The total length of the leg was 53.3 days, of which 35.2 days were spent on site, 8.1 days in a sched- 
uled port call, and 6.5 days in transit (Table 1). Mechanical breakdowns accounted for 3.5 days.

Various bottom-hole assembly (BHA) configurations were employed during Leg 80 . The standard DSDP rotary coring assembly (see Explanatory Notes, this volume) was used for Holes 548A and 549. The variable length hydraulic piston corer (VLHPC) was used at Holes 548 and 549A, which required some modification of the BHA. Hydraulic piston coring was not elected at either of the final two sites (550 and 551).

Drilling Hole 548 turned out to be a good test of the VLHPC system. The very long assembly was successfully deployed in the moderate to severe vessel motion conditions that prevailed. Handling was awkward, as had been anticipated, but the equipment was definitely manageable. Where thick blankets of relatively soft sediments are present, the rapid recovery of $9.5 \mathrm{-m}$ cores saves enough time to offset the system's disadvantages (mainly awkwardness in handling) at deep water sites.

The core barrel had a quick-disconnect feature and a new shear pin arrangement; both proved to be major improvements over the old system. The shear pins failed three times at Hole 548 before the corer reached the bit. The failures were attributed to the action of the surge in the pipe (due to vessel motion) on the weight of the corer.

No significant mechanical problems were experienced with the drilling and coring equipment. The hydraulic bit release was actuated successfully (eventually) at each of the three sites where it was deployed. None of the releases was straightforward or according to design, however, so there are serious questions about the system's reliability.

Core bits featuring various cutting structures were used. All were successful in that no holes had to terminated as a result of bit failure. The shop-fabricated bit used in Hole 549 featured Hughes cutters with a cutting structure only slightly different from the more familiar Smith F94CK. Penetration rate was unexpectedly low in lithologies that contained clay, however. This bit unexpectedly continued to work for more than 60 operating hours after reduced core diameter first signaled the failure of at least one bearing, and the site's drilling objective was reached. F93CK bits were used at the last two sites, and the long chisel cutting structure proved to be the most efficient for the sediments in the leg operating area. Both of the F93CK bits also cored considerable intervals of basalt without damage to the cutting structure.

Downhole logs were recorded at Sites 548, 549, and 550. In total, six logging runs were made; the total open-hole logged interval was $3377.5 \mathrm{~m}$. No logging was carried out at Site 551 because of the shallow penetration and the constraint of time. All the logs except the sonic $\log$ at Hole 549 were of good quality.

Most of the technical problems encountered during logging were caused, either directly or indirectly, by one component-the three-arm caliper/centralizer. A cursory inspection revealed that the caliper was too large in diameter to pass through the drill pipe, and major modifications in the ship's machine shop were eventually necessary before the two caliper units on board could pass through all components of the drill string. Then, during each of the sonic log runs, the caliper operating mechanism became fouled with sediment. The fouling caused a shift or displacement in the caliper data curve, invalidating the careful calibration done on the rig floor and making it necessary to subject the caliper data to the uncertainties of correction using bit and pipe diameters. The caliper/centralizer also provides centralization for the sonic velocity sonde; the sonde must be centered to control noise and prevent "cycle skipping" (loss of signal or spurious spikes in the signal). The sonic caliper $\log$ recorded in Hole 549 indicated that the springs of

Table 1. Coring summary, Leg 80 .

\begin{tabular}{|c|c|c|c|c|c|c|c|c|c|c|c|c|c|}
\hline Hole & Latitude & Longitude & $\begin{array}{c}\text { Water } \\
\text { depth } \\
\text { (m) }\end{array}$ & $\begin{array}{c}\text { Number } \\
\text { of } \\
\text { cores }\end{array}$ & $\begin{array}{l}\text { Cores } \\
\text { with } \\
\text { recovery }\end{array}$ & $\begin{array}{l}\text { Percent of } \\
\text { cores with } \\
\text { recovery }\end{array}$ & $\begin{array}{l}\text { Meters } \\
\text { cored }\end{array}$ & $\begin{array}{c}\text { Meters } \\
\text { recovered }\end{array}$ & $\begin{array}{l}\text { Percent } \\
\text { recovered }\end{array}$ & $\begin{array}{l}\text { Meters } \\
\text { drilled }\end{array}$ & $\begin{array}{l}\text { Total } \\
\text { penetration } \\
\text { (m) }\end{array}$ & $\begin{array}{c}\text { Average } \\
\text { penetration } \\
\text { rate } \\
(\mathrm{m} / \mathrm{hr})^{\mathrm{c}}\end{array}$ & $\begin{array}{c}\text { Time on } \\
\text { hole or } \\
\text { site } \\
\text { (hr.) }\end{array}$ \\
\hline 548 & $48^{\circ} 54.95^{\prime} \mathrm{N}$ & $12^{\circ} 09.84^{\prime} \mathrm{W}$ & 1256 & 35 & 35 & 100.0 & 211.0 & 210.9 & 99.9 & 0 & 211.0 & & 45.2 \\
\hline \multirow[t]{2}{*}{$548 \mathrm{~A}$} & $48^{\circ} 54.93^{\prime} \mathrm{N}$ & $12^{\circ} 09.87^{\prime} \mathrm{W}$ & 1256 & 38 & 38 & 100.0 & 346.0 & 246.5 & 71.2 & 205.5 & 551.5 & 42.4 & 82.9 \\
\hline & & \multicolumn{2}{|c|}{ Total for site } & 73 & 73 & 100.0 & 557.0 & 457.4 & 82.1 & 205.5 & 762.5 & & 128.1 \\
\hline \multirow{3}{*}{$\begin{array}{l}549 \\
549 \mathrm{~A}\end{array}$} & $49^{\circ} 05.28^{\prime} \mathrm{N}$ & $13^{\circ} 05.88^{\prime} \mathrm{W}$ & 2533 & 99 & 93 & 93.9 & 812.5 & 369.7 & 45.5 & 189.0 & 1001.5 & 7.9 & 301.2 \\
\hline & $49^{\circ} 05.29^{\prime} \mathrm{N}$ & $13^{\circ} 05.89^{\prime} \mathrm{W}$ & 2535.5 & 42 & 41 & 77.6 & 196.0 & 144.4 & 73.7 & 0 & 198.5 & & 54.2 \\
\hline & & \multicolumn{2}{|c|}{ Total for site } & 141 & 134 & 95.0 & 1008.5 & 514.1 & 51.0 & 189.0 & 1200.0 & & 355.4 \\
\hline 550 & $48^{\circ} 30.91^{\prime} \mathrm{N}$ & $13^{\circ} 26.37^{\prime} \mathrm{W}$ & 4432 & 48 & 46 & 95.8 & 442.5 & 262.6 & 59.3 & 94.0 & 536.5 & 36.4 & 115.3 \\
\hline $550 \mathrm{~A}$ & $48^{\circ} 30.91^{\prime} \mathrm{N}$ & $13^{\circ} 26.39^{\prime} \mathrm{W}$ & 4432 & 0 & 0 & 0 & 0 & 0 & 0 & 95.0 & 95.0 & 170.6 & 19.2 \\
\hline \multirow[t]{2}{*}{$550 \mathrm{~B}$} & $48^{\circ} 30.96^{\prime} \mathrm{N}$ & $13^{\circ} 26.32^{\prime} \mathrm{W}$ & 4432 & 30 & 30 & 100.0 & 264.5 & 177.9 & 67.3 & 456.0 & 720.5 & 14.2 & 150.3 \\
\hline & & \multicolumn{2}{|c|}{ Total for site } & 78 & $\overline{76}$ & 97.4 & $\overline{707.0}$ & $\overline{440.5}$ & 62.3 & $\overline{645.0}$ & $\overline{1352.0}$ & $34.0^{\mathrm{d}}$ & $\overline{284.8}$ \\
\hline \multirow[t]{2}{*}{551} & $48^{\circ} 54.64^{\prime} \mathrm{N}$ & $13^{\circ} 30.09^{\prime} \mathrm{W}$ & 3909 & 14 & 13 & 92.9 & 125.0 & 81.0 & 64.8 & 76.0 & 201.0 & 9.1 & 75.2 \\
\hline & & \multicolumn{2}{|c|}{ Total for leg } & 306 & $\overline{296}$ & 96.7 & $\overline{2397.5}$ & $\overline{1493.0}$ & 62.2 & 1115.5 & 3515.5 & & 843.5 \\
\hline
\end{tabular}

Note: Blanks signify that quantities are unknown.

a Total for site is calculated from total number of cores and total cores with recovery.

b Total for site is calculated from total meters cored and total meters recovered.

c Rotary coring only.

d Total meters penetrated divided by number of rotating hours. 
the unit used for centralization were too weak to keep the long, heavy sonic/induction/gamma ray tool from touching the side of the hole. The hole deviated about $6^{\circ}$ from vertical, and the caliper often produced readings that were smaller than bit size, indicating that the caliper springs were being collapsed by lateral forces. Unfortunately, the caliper on the density/neutron tool, a device of different design, also failed to perform properly during the leg.

During logging operations at Hole 549, the caliper/ centralizer would not pass through the circulating head installed at the top of the drill pipe. This led to a change in recovery procedures and, ultimately, to the fouling and loss of the tool. The subsequent fishing job cost 5.5 hr. of rig time and precluded further logging in the hole. One sonic tool and the only dual induction tool were damaged beyond shipboard repair and could not be used for the remaining holes. The success of the fishing operation at Site 549 was due to good fortune and the availability of coring equipment that could be adapted for fishing. No fishing tools were provided in the logging contract.

The large logging tools now in use (up to $22 \mathrm{~m}$ in length and $1800 \mathrm{lb}$ in weight) have several advantages over the smaller, lighter sondes used in the past. They allow records to be made of sonic velocity, resistivity, formation density, and neutron porosity and redundant records to be made of the gamma ray and caliper curves in just two runs through the drill hole. In addition, the weight of the tools causes them to break through minor bridges and to push past obstructions that would stop smaller, lighter tools. This characteristic is important in view of the poor hole conditions that normally exist in DSDP holes.

The principal disadvantages of these tool configurations are that they are difficult to assemble and disassemble and awkward to put into and remove from the drill pipe. The sonic/dual induction assembly, which weighs $1800 \mathrm{lb}$, is $22 \mathrm{~m}$ long, and has a $24-\mathrm{m}$ bridle attached, is especially awkward. The suspended sonde has very little rigidity and is difficult to handle with any amount of vessel motion. One sonic tool is believed to have been damaged during attempts to start it into the pipe. A lesser but sometimes important disadvantage of long sondes is that sensors located near the top do not record several meters at the bottom of the hole. This means that more "rathole" has to be drilled to permit the lowest desired lithology to be logged.

The cooperativeness, ingenuity, and acuity of the Leg 80 logging engineer, in combination with the capabilities of some sophisticated computerized equipment, produced some breakthroughs in the acquisition and manipulation of logging data. Sonic velocity logs reading directly in kilometers per second were produced for the first time, as well as computed acoustic impedance logs and cross-plot presentations of various measurements.

The overall performance of the vessel's dynamic positioning system was very good; no operational problems were experienced. It did become necessary to change the vertical reference gyro units on two occasions at Site 549, but this was done without interrupting operations. There were also several instances of instability in the positioning system in which thrust was applied in response to obviously false displays of position error. This is an old and chronic problem that appears under conditions of deep water and considerable vessel pitch.

All the positioning beacons were single-life models manufactured by Ocean Research Equipment (ORE). Both 13.5- and $16.0-\mathrm{kHz}$ frequencies were used, and no problems arose.

Weather conditions were better than expected for the operating area. Adverse conditions prevailed for about the first week of operations at Site 548 and for about a week during work at Site 550. During the second inter$\mathrm{val}$ it became necessary to abort Hole 550, and there was a 2-day interruption in coring operations as a result of 35 -mph winds, the maximum recorded on the voyage.

Currents, which were generally from the west, were weak or absent much of the time. They seemed to increase in the wake of unstable weather, however, and became a factor in positioning on one or two occasions.

The effects of tides are normally so slight during DSDP operations as to be insignificant. During Leg 80 , several drilling depth discrepancies provided evidence of a tidal range of at least $3 \mathrm{~m}$, however. The range and times were in approximate agreement with the tide cycle at such nearby points as Cobh, Ireland, the Scilly Isles, and Land's End.

\section{REFERENCES}

Auffret, G. A., Pastouret, L., Cassat, G., de Charpal, O., Cravatte, J., and Guennoc, P., 1979. Dredged rocks from the Armorican and Celtic margins. In Montadert, L., Roberts, D. G., et al., Init. Repts. DSDP, 48: Washington (U.S. Govt. Printing Office), 995-1008.

Bally, A. W., Bernoulli, D., David, G. A., and Montadert, L., 1981. Listric normal faults. Proc. 26th Internat. Geol. Congr., Paris 1980, Oceanol. Acta, Suppl., 4:87-101.

Dingle, R. V., and Scrutton, R. A., 1979. Sedimentary succession and tectonic history of a marginal plateau (Goban Spur, southwest of Ireland). Mar. Geol., 33:45-69.

Evans, C. D. R., Lott, G. K., and Warrington, G., 1981. The Zephyr (1977) wells, South-Western Approaches and western English Channel. Sci. Rept. Inst. Geol., 81(8).

Kamerling, P., 1979. The geology and hydrocarbon habitat of the Bristol Channel Basin. J. Petrol. Geol., 2:75-93.

Masson, D. G., and Roberts, D. G., 1981. Late Jurassic-Early Cretaceous reef trends on the continental margin south-west of the British Isles. J. Geol. Soc. London, 138:437-443.

Montadert, L., Roberts, D. G., et al., 1979. Init. Repts. DSDP, 48: Washington (U.S. Govt. Printing Office).

Montadert, L., Roberts, D. G., de Charpal, O., and Guennoc, P., 1979. Rifting and subsidence of the northern continental margin of the Bay of Biscay. In Montadert, L., Roberts, D. G., et al., Init. Repts. DSDP, 48: Washington (U.S. Govt. Printing Office), 1025-1060.

Naylor, D., and Shannon, P., 1983. Geology of Offshore Ireland and West Britain: London (Graham and Trotman).

Pastouret, L., Auffret, G. A., Auzende, J. M., Beuzart, P., Dubois, P., Seguret, M., Sigal, J., and Vanney, J. R., 1981. La marge continentale armoricaine: Résultats d'observations en submersible et de dragages dans le canyon Shamrock. C. R. Acad. Sci. Paris, 292 (Ser. III), 741-748.

Pautot, G., Renard, V., de Charpal, O., Auffret, G. A., and Pastouret, L., 1976. A granite cliff deep in the North Atlantic. Nature, 263: 669-672. 
Roberts, D. G., 1975. Marine geology of the Rockall Plateau and Trough. Phil. Trans. R. Soc. London Ser. A, 278:447-509.

Roberts, D. G., and Jones, M. T., 1975. Magnetic anomalies in the northeast Atlantic, Sheets 1 and 2. Mtg. European Geol. Soc. (Abstract)

Roberts, D. G., Masson, D. G., and Montadert, L., 1981. Continental margin from the Porcupine Seabight to the Armorican marginal basin. In Illing, L. V., and Hobson, G. D. (Eds.), Petroleum Geology of the Continental Shelf of North-West Europe: London (Institute of Petroleum), pp. 455-473.

Roberts, D. G., and Montadert, L., 1979. Margin paleoenvironments of the northeast Atlantic. In Montadert, L., Roberts, D. G., et al., Init. Repts. DSDP, 48: Washington (U.S. Govt. Printing Office), 1009-1118.

Robinson, K. W., Shannon, P. M., and Young, D. G. D., 1981. The Fastnet Basin: an integrated analysis. In Illing, L. V., and Hobson, G. D. (Eds.), Petroleum Geology of the Continental Shelf of North-West Europe: London (Institute of Petroleum), pp. 444-454.

Scrutton, R. A., 1979. Structure of the crust and upper mantle at Goban Spur, southwest of the British Isles-some implications for margin studies. Tectonophysics, 59:201-215.

Tucholke, B. E., and Vogt, P. R., 1979. Western North Atlantic: sedimentary evolution and aspects of tectonic history. In Tucholke, B. E., Vogt, P. R., et al., Init. Repts. DSDP, 43: Washington (U.S. Govt. Printing Office), 791-825.

Vail, P. R., Mitchum, R. M., Todd, R. G., Widmier, J. M., Thompson, S., III, et al., 1977. Seismic stratigraphy and global changes of sea level. In Payton, C. E. (Ed.), Seismic Stratigraphy-Applications to Hydrocarbon Exploration. Mem. Am. Assoc. Pet. Geol., 26:45-212.

Date of Initial Receipt: September 6, 1983

Date of Acceptance: November 9, 1983 